\title{
Determining pledged loan-to-value ratio: an option pricing perspective
}

\author{
Ran Zhang*, Jing Zhang and Shuang Xu
}

\author{
* Correspondence: ranzhangrz@163. \\ com \\ Dongling School of Economics and \\ Management, University of Science \\ and Technology Beijing, 30 \\ Xueyuan Road, Haidian District, \\ Beijing 100083, P. R. China
}

\begin{abstract}
Background: We investigated the determination of the pledged loan-to-value ratio in an optionpricing environment and mainly articulated the theoretical framework and analytical method.

Methods: The basic idea is that the present value of the pledged loan payoff is equal to a put option's value.While the interest rate is fixed and the loan is without coupon, we analyzed the pledged loan-to-value ratioin the option pricing perspective and got it that the pledged loan-to-value ratio is decided by term, excessreturn, and the value volatility of the pledge. Next, we extended the same work to coupon loan and portfoliopledge circumstances. For zero coupon and fixed interest rate circumstances, we performed a numericalanalysis.
\end{abstract}

Results: Our results indicate the following:the pledged loan-to-value ratio is a convex decreasing function ofthe term; and the pledged loan-to-value ratio is a concave decreasing function of the value volatility of the pledge; and the pledged loan-to-value ratio is a concave increasing function of the risk premium. For floating interest rate circumstances, we should specify the function form between the loan interest and the risk-free rate.

Conclusions: The scientific measurement of the pledged loan-to-value ratio means that simple rules of thumb or the VaR method may lead to mispricing, which could create the possibility of arbitrage. In this way, a new direction for trading derivative products of pledges will be provided.

Keywords: Pledged loan, Loan-to-value ratio, Put option, Term structure of pledged ratio, Value volatility of pledge

\section{Background}

Inventory pledge loans are one of the most important financial instruments in banks, which exceed real estate pledged loans. Compared with international banks, the proportion of inventory pledge loans in China is smaller and develops slowly. Therefore, the rapid development of Chinese modern service industry has been restricted to a particular extent, for example, the logistics and financial industries' ability to promote growth in real economy has been restricted. During the inventory pledge loan process, the value of pledges changes with time and those with sufficiently high values reduce the credit risk of banks. One of the key risk management problems of banks is to determine a reasonably pledged loan-to-value ratio, a rate of pledge loans, and a pledge value. Therefore, looking for a scientific method to determine a pledged loan-to-value

\section{Springer}

(c) 2015 Zhang et al. Open Access This article is distributed under the terms of the Creative Commons Attribution 4.0 International License (http://creativecommons.org/licenses/by/4.0/), which permits unrestricted use, distribution, and reproduction in any medium provided you give appropriate credit to the original author(s) and the source, provide a link to the Creative Commons license, and indicate if changes were made. 
ratio is the first necessity of sound and for the rapid development of the inventory pledge loan business.

In foreign mature capital markets, the practice and research of pledge loans is different from ours. In foreign countries, there is a developed asset securitization market, and the focus of theoretical research is the pricing of asset securitization under the conditions of a given pledged loan-to-value ratio. On the contrary, in our country, because most of the credit assets lack liquidity and a secondary market to trade in, at present, the pledged loan-to-value ratio of storage pledge loans in our banking industry is generally defined as $70 \%$. Therefore, our core research problem is to determine the pledged loan-to-value ratio under the premise of reasonable pricing, which means solving the inverse problem of similar foreign research. Literature on pledged loan-to-value ratio is rare. Stulz and Johnson (1985)first used Merton's (1973) structural method to study the effects of the pledge on pledged collateral debt pricing. On that basis, Jokivuolle and Peura (2003) calculated the default probability of a loan enterprise to establish the relationship between loan loss and the pledged loan-to-value ratio. When pricing a mortgage-backed credit risk tool, Cossin and Hricko (2003) identified the discount rate of the pledge (subtract pledged loan-to-value ratio from 1). Korteweg and Sorensen (2015) used a Bayesian filtering procedure to recover the price path for individual properties and produce selection-corrected estimates of historical combined loan-to-value ratios distributions. Using the simplified method proposed by Jarrow and Turnbull (1995); Jarrow et al (1997) and Duffie and Singleton (1999); Cossin et al (2003) proposed a pledged loan-to-value ratio that is consistent with a bank's risk tolerance. Buzacott and Zhang (2004) studied financing based on assets from the perspective of the enterprise; they combined bank risk management with enterprise inventory management for the first time and analyzed the choice of interest rate and pledged loan-to-value ratio and their effects on the bank's and the enterprise's profitability. Using a unique micro dataset compiled from official real estate registries in Japan, Arito et al (2013) found that the LTV ratio exhibits countercyclicality, implying that the increase (decrease) in loan volumes is smaller than the increase (decrease) in land values during booms (busts). Similar domestic research has not reached that level. Domestic researchers have mainly used the empirical method and the value at risk (VaR) method and alike methods. Wang (2003); Fan and Wei (2003) and Huang et al (2009) used the $\mathrm{VaR}$ method to research the manner of determining the pledged loan-to-value ratio from the perspective of the bank loans' market risk and credit risk management. He et al (2012) presented the calculation of long-term risk VaR under thick tail distribution, and obtained the loan-to-value ratio in accord with the risk tolerance of bank. Li et al (2007) applied the risk assessment strategy of "subject + debt" to study banks' pledged loan-to-value ratio determination with downside risk aversion on the condition that the final price of the pledged inventory would follow general and several specific distributions. Qi et al (2008) researched the pledged loan-to-value ratio of loans pledged against combined warehouse receipts. They assumed that the prices of various relative commodities obeyed a copula function, determined a unified pledged loan-tovalue ratio of all pledged goods from the same enterprise, regarded the total cost to the bank as the objective function, and then established nonlinear programming to obtain the optimal pledged loan-to-value ratio. Zhang and Zhao (2010) analyzed the optimal pledged loan-to-value ratio decision of the bank when the demand of inventory fluctuated randomly. By constructing stock loan-to-value ratio model under the condition of the risk 
neutral or risk preference, Wang et al (2013) studied the decision of the highest quality pledged rate, and analyzed the influence of different risk preferences loan-to-value ratios. Based on default adjusted spread principle, low carbon adjusted spread principle and pledge risk control principle, Kuang et al (2013) made the interest rate decision model of pledged loan, the pledge of which is the liquid inventory in low carbon ports. These studies had a common characteristic; they only considered the probability characteristics of the pledged property and did not make full use of other market information, for example, the risk-free interest rate. Consequently, these studies had few limitations. In a pledge loan market, the term and the interest rate of the loan are decided by the supply side and the demand side. In this case, an analysis of the term structure and the interest rate structure of the pledged loan-to-value ratio is necessary, and this is not addressed in the existing literature.

In this paper, we used the option pricing method to systematically analyze the pricing of an inventory pledge loan and emphasized the pledged loan-to-value ratio. Compared with existing domestic research, the method of this paper has rich theoretical implications. First, each different loan term has its own pledged loan-to-value ratio, thus this method allows us to determine the term structure of the pledged loan-to-value ratio. Second, the method can be used to analyze the relationship between the pledged loanto-value ratio and the loan interest rate. Third, volatility influences the pledged loan-tovalue ratio, and therefore, this method can be used to analyze the manner in which the pledged loan-to-value ratio varies with different types of metals pledged. Lastly, risk attitude affects the determination of the pledged loan-to-value ratio. The major limitation of this method is that the matter pledged should be tradable. The option pricing method requires that the sales of the underlying assets can be transacted dynamically with a low cost. If the pledged property exists, a dynamic hedge of its corresponding futures product (for example, metal futures) can be achieved by futures trading. For a pledged property with futures that are non-tradable or require expensive transactions, we should introduce risk appetite or use the traditional method for analysis. The main purpose of this paper is to articulate the theoretical framework and analytical method; the concrete conclusion and empirical implications will be offered in follow-up studies. Compared to the previous version, this paper summarizes and analyzes more related literature in recent years.

\section{Fixed interest rate and zero coupon model}

In our loan market at present, the operation mode of inventory pledge loans varies. The term, interest rates, and interest payments are very flexible. Different banks with different businesses have different treatments. Specific to each business, the concern whether to pay interest and how to pay it with principal or regularly, can be determined by both parties of the loan. In this study, we first analyzed zero-coupon loans with fixed interest rates, and then, we extended to analyze loans with continuous or interval interest payments.

\section{The problem}

In general, the value of the loan is a nonlinear function of the pledge value, i.e., the pledged loan-to-value ratio depends on the pledge value. Therefore, the key problem of our study can be stated as follows. 
We suppose the following: the continuous compound risk-free interest rate is $r$, the current moment is $t$, the amount of a zero-coupon loan is $D$, the maturity date is $T$, the continuous compound interest rate with no interest payment before the maturity date is $R$, and the value of the pledged assets is $V$. Define the pledged loan-to-value ratio as $x=D / V$, and then calculate the loan-to-value ratio $x(V)$.

According to the above definition, one can apply for a loan with amount $x V(t)$. The maturity value $P(T)$ can be stated as follows:

$$
P(T)=\min \left[V(T), x V(t) e^{R(T-t)}\right]
$$

$P(T)$ can be decomposed into the following:

$$
P(t)=x V(t) e^{R(T-t)}-\max \left[x V(t) e^{R(T-t)}-V(T), 0\right]
$$

In equation (2), the first item is definite. It can be regarded as an amount of risk-free assets and is the value of the loan without the probability of default. The second item is an amount of contingent assets, which equals a put option. At maturity, if the value of the loan is more than the value of the pledged assets, the loan will default. At maturity, if the value of the loan is more than the value of the pledged assets, the borrower will default and the investor will lose the difference. For the investor, this is equivalent to issuing a risk-free loan and selling a put option at the same time. The strike price of the put option is $K=x V(t) e^{R \tau}, \tau=T-t$.

Using the put option pricing formula

$$
\Phi=e^{-r \tau} E_{t}^{Q}\left\{\max \left[x V(t) e^{R \tau}-V^{Q}(T), 0\right]\right\}
$$

we can get the current value of combination (2).

$$
P(t)=K e^{-r \tau}-\Phi(K, V(t), \tau)
$$

To guarantee the loan pricing recognized by both investors and financiers, we applied the principle of fair pricing on loans.

The principle of fair pricing: the present value is equal to the amount of the loan.

$$
P(t)=x V(t)
$$

This is the determining equation of the pledged loan-to-value ratio $x$.

Theorem 1: In general, the value of the pledged assets $V$, the risk-free rate $r$, the maturity date of the fixed-rate zero-coupon loans $T$, the current time $t$, the loan rate $R$, and the volatility of the pledged assets determine the pledged loan-to-value ratio. The determining equation of the pledged loan-to-value ratio is as follows:

$$
x V(t) e^{(R-r) \tau}-\Phi(x, V(t), R, T, t)=x V(t)
$$

\section{General properties}

There is a more intuitive interpretation of the determination of the pledged loan-tovalue ratio, which we can see if we rearrange equation (5).

Theorem 2: The fair pledged loan-to-value ratio makes the present value of the excess earnings equal to the value of a put option. 


$$
\Phi(x, V(t), R, T, t)=e^{-r \tau} x V(t)\left(e^{R \tau}-e^{r \tau}\right)
$$

Theorem 3: If the probability distribution of the pledged assets yield does not depend on the value of the pledged assets $V$, then $x$ does not depend on $V$, and the loanable amount is a linear function of the value of the pledged assets.

$$
\Phi\left(e^{R \tau}, 1 / x, \tau\right)=e^{(R-r) \tau}-1
$$

Proof of theorem 3: According to Merton (1973), theorem 9, if the probability distribution of the pledged assets yield does not depend on the value of the pledged assets $V$, the value of the put option is a homogeneous function of the strike price and the current value of the pledged assets.

$$
\Phi(K, V(t), \tau) \triangleq \Phi\left(x V(t) e^{R \tau}, V(t), \tau\right)=x V(t) \Phi\left(e^{R \tau}, 1 / x, \tau\right)
$$

Take this into equation (5):

$$
x V(t) e^{(R-r) \tau}-x V(t) \Phi\left(e^{R \tau}, 1 / x, \tau\right)=x V(t)
$$

Because $V(t)$ is greater than 0 , we can get equation (7) after rearranging.

Suppose further that the value of the pledged assets $V$ follows the diffusion stochastic process,

$$
d V(t)=\mu(V, t) d t+\sigma(V, t) d z
$$

where $d z$ is a standard Brownian motion under the objective probability measure $P$. Under the risk-neutral probability measure $Q$,

$$
d V^{Q}(t)=r\left(V^{Q}, t\right) d t+\sigma\left(V^{Q}, t\right) d z^{Q}
$$

where $d z^{Q}$ is a standard Brownian motion under probability measure $Q$.

Theorem 4: For equation (8), the dependency of the pledged loan-to-value ratio on $R$ and $r$ can only be reflected by risk premium $R-r$.

Proof of theorem 4: According to equation (5), we only need to prove that $\Phi$ depends on $R-r$. According to equation (3),

$$
\begin{aligned}
\Phi & =e^{-r \tau} E^{Q}\left\{\max \left[x V(t) e^{R \tau}-V^{Q}(T), 0\right]\right\} \\
& =e^{(R-r) \tau} E^{Q}\left\{\max \left[x V(t)-e^{-R \tau} V^{Q}(T), 0\right]\right\}
\end{aligned}
$$

Using Itō's lemma, under the probability measure $Q$, the dependency of the $e^{-R(T-t)} V(T)$ distribution on $R$ and $r$ can only be reflected by $R-r$. Then we can conclude that the dependency of $x$ on $R$ and $r$ can only be reflected by $R-r$.

Theorem 5: If the probability distribution of $V$ is stable, i.e., $\mu(V, t)$ and $\sigma(V, t)$ in equation (8) do not depend on time; the pledged loan-to-value ratio depends only on $\tau=T-t$.

Proof of theorem 5: According to equation (9), the probability distribution of $V^{Q}(T)$ can be written as $F(V, \tau)$, and the value of the option can be written as $\Phi(V, \tau)$. The equation of the pledged loan-to-value ratio is as follows:

$$
\Phi(V, \tau)=x V\left[e^{(R-r) \tau}-1\right] .
$$

Thus, $x$ can be written as $x(V, \tau)$. 


\section{Black-scholes model and pledged loan-to-value ratio}

The assumption that stock price follows a geometric Brownian motion has been widely accepted by academia and industry. Because the transaction frequency and the price change frequency of the commodity are lower than those of the financial assets, using the hypothesis of a geometric Brownian motion to describe the change in the commodity price is not intuitive, but it is still reasonable. Especially when we research the pledge loans of commodities such as agricultural products, metals, and oil for which futures trading exists, the rationale is more obvious. For example, studies by Fernando et al. (2006); Alvarez-Ramirez et al (2008), and others considered that geometric Brownian motion could well depict the price of petrol. Therefore, for the convenience of analysis, we assume that the value of a pledged property follows a geometric Brownian motion

$$
\frac{d V}{V}=\mu d t+\sigma d z
$$

Obviously, a geometric Brownian motion meets the assumptions in theorem 2 to theorem 5. If we redefine the variable $R-r=k$, the corresponding pledged loan-to-value ratio can be written as $x(k, \tau, \sigma)$. We can see that the pledged loan-to-value ratio is decided by the risk premium $R-r$, loan term, and the value volatility of the pledged property.

Under the assumption that the price of pledged property follows a geometric Brownian motion, we can obtain explicit solutions for the option price. For a European put option with present price $S$ and strike price $T$, using the standard Black and Scholes (1973) put option pricing formula, we can get $\Phi$ as follows:

$$
\Phi=K e^{-r(T-t)} N\left(-d_{2}\right)-S N\left(-d_{1}\right),
$$

where $N($.$) is the probability distribution function of standard normal distribution. The$ other parameters are the same as in the above-mentioned definition.

$$
d_{1}=\frac{\log \left(\frac{S}{K}\right)+\left(r+0.5 \sigma^{2}\right)(T-t)}{\sigma \sqrt{T-t}}, d_{2}=\frac{\log \left(\frac{S}{K}\right)+\left(r-0.5 \sigma^{2}\right)(T-t)}{\sigma \sqrt{T-t}},
$$

In this paper, the value of the put option is

$$
\Phi=x V(t) e^{(R-r)(T-t)} N\left(-d_{2}\right)-V(t) N\left(-d_{1}\right),
$$

where

$$
d_{1}=\frac{-\log (x)+\left(0.5 \sigma^{2}-k\right) \tau}{\sigma \sqrt{\tau}}, d_{2}=\frac{-\log (x)+\left(-0.5 \sigma^{2}-k\right) \tau}{\sigma \sqrt{\tau}} .
$$

Because $N(x)+N(-x)=1$, we can obtain the determining equation of the pledged loanto-value ratio.

Theorem 6: If the price of the pledged property follows a geometric Brownian motion, the determining equation of the pledged loan-to-value ratio is as follows:

$$
e^{k \tau} N\left(d_{2}\right)=1-\frac{1}{x} N\left(-d_{1}\right),
$$

where $d_{i}, i=1,2$ is defined by equation (12).

Equation (13) is a nonlinear algebraic equation of $x$; we can use a numerical algorithm to get the explicit solution of $x$. 


\section{Further discussion \\ Pledged loan-to-value ratio of continuous-interest-payment, fixed-rate, and indefinite loans}

The basic method previously used to analyze the zero-coupon loan can be extended to interest-bearing loans directly. First, we consider continuous-interest-payment loans. The fixed interest rate is $R$. To get the analytical solution, we assume that the length of maturity is indefinite. The solution for a limited situation can be obtained using a numerical algorithm. Suppose that the price of a pledged property follows a geometric Brownian motion, the value of the pledged property is $P$, the lending moment is 0 , and the interest paid each time is $R x V(0)$. Then, $P$ satisfies the following equation:

$$
r P=R x V(0)+\Theta(P)
$$

here, the operator $\Theta$ is defined as follows:

$$
\Theta(P) \triangleq P_{V} r V+0.5 P_{V V} \sigma^{2} V^{2}
$$

where $P_{V}$ is the first-order derivative of $P$ to $V$ and $P_{V V}$ is the second-order derivative of $P$ to $V$.

To solve equation (14), we need to know the boundary condition. The main content of the boundary conditions is the default time when the borrower stops paying interest and terminates the contract. For fixed-rate zero-coupon loans, the default time is easy to determine, because the borrower can only default at the maturity date. However, for interest-bearing loans, the borrower has the right to decide the default time $\tau$. In this situation, the loan contract has the characteristics of an American option. As a result, the economic implication of the default time is that the borrower chooses the best time to default. Mathematically speaking, that requires the following two conditions.

Continuity condition: When the borrower defaults, the value of the pledged assets is equal to the value of the loan. The economic implication is that if the value of the pledged property is greater than the value of the loan, the borrower should not give up the pledged property and should not default, and if the pledged property value is less than the value of the loan, the borrower should not continue to repay the loan and should default. Therefore, when the borrower defaults, the value of the pledged assets must be equal to the value of the loan.

$$
\phi=\min [t, P(t)=V(t)]
$$

Smoothness condition: When the borrower defaults, the value function is smooth, i.e., the slope before defaulting is equal to the slope after defaulting. This is an optimization condition. Borrowers will choose the optimal timing from all the alternatives that satisfy the continuity condition. This makes the increased value of the borrower largest, and the slope of the increased value function is equal to 0 .

Equation (14) is an ordinary differential equation the solution that consists of a particular solution and the general solution of a homogeneous part. The particular solution is as follows:

$$
P(V)=\frac{R x}{r} V(0) .
$$

The general solution of homogeneous part $r P=\Theta(P)$ is 


$$
P(V)=\frac{R x}{r} V(0)+C V^{\theta_{-}},
$$

where $C$ is an undetermined constant and $\theta=-\frac{2 r}{\sigma^{2}}$ is the solution of the following algebraic equation

$$
0.5 \sigma^{2} \theta^{2}+\left(r-0.5 \sigma^{2}\right) \theta-r=0 .
$$

According to the continuity condition and the smoothness condition, we choose $\bar{V}$, which makes

$$
\left\{\begin{array}{l}
\frac{R x}{r} V(0)+C \bar{V}^{\theta_{-}}=\bar{V} \\
\theta_{-} C \bar{V}^{\theta_{-}-1}=1
\end{array} .\right.
$$

Then, we can get

$$
\begin{aligned}
& \bar{V}=\frac{R x}{r}\left(\frac{\theta_{-}}{\theta_{-}-1}\right) V(0) \\
& P(V)=\frac{R x}{r} V(0)+\frac{R x}{r} V(0)\left(\frac{1}{\theta_{-}-1}\right)\left(\frac{V}{\bar{V}}\right)^{\theta_{-}} .
\end{aligned}
$$

Theorem 7: For a continuous-interest, fixed-rate, and indefinite loan where the price of the pledged property follows a geometric Brownian motion, the pledged loan-tovalue ratio is

$$
x=\left[\frac{r-R}{R}\left(\theta_{-}-1\right)\right]^{-\frac{1}{\theta_{-}}} \frac{r}{R}\left(\frac{\theta_{-}-1}{\theta_{-}}\right) .
$$

Proof of theorem 7: The determining equation of the pledged loan-to-value ratio is as follows:

$$
\frac{R x}{r} V(0)+\frac{R x}{r} V(0)\left(\frac{1}{\theta_{-}-1}\right)\left(\frac{V}{\bar{V}}\right)^{\theta_{-}}=x V .
$$

Using equation (18) and rearranging it, we can get equation (19).

\section{Pledged loan-to-value ratio of interval-interest-payment and fixed-rate loans}

A more realistic situation is paying interest at intervals. Consider a pledge loan contract paying interest at intervals. Interest dates are $\tau_{1}, \tau_{2}, \cdots, \tau_{n-1}, \tau_{n}$, and the corresponding payments are $C_{1}, C_{2}, \cdots, C_{n-1}, C_{n}$. Obviously, an ordinary fixed-rate loan is a specific case of this type.

In this situation, we could use a recursive method to get the solution. Assume that the pricing function of the loan is $\Gamma_{\tau}(V(T))$, which means the value of $V(T)$ at the moment $\tau$. In $\left[\tau_{n-1}, \tau_{n}\right]$, the value of the loan is equal to the determining equation of the fixed-rate zero-coupon loan mentioned previously.

$$
P(\tau)=\Gamma_{\tau}\left[\min \left[V\left(\tau_{n}\right), C_{n}\right]\right], \tau>\tau_{n-1}
$$

At the moment $\tau_{n-1}$, 


$$
\begin{aligned}
P\left(\tau_{n-1}\right) & =\min \left[C_{n-1}+P\left(\tau_{n-1}^{+}\right), V_{\tau_{n-1}}\right] \\
& =\min \left[C_{n-1}+\Gamma_{\tau_{n-1}^{+}}\left[\min \left[V\left(\tau_{n}\right), C_{n}\right]\right], V_{\tau_{n-1}}\right]
\end{aligned}
$$

In $\left(\tau_{n-2}, \tau_{n-1}\right)$, the value of the loan is as follows:

$$
P_{\tau_{n-1}-\tau_{n-2}}(\tau)=\Gamma_{\tau}\left[P\left(\tau_{n-1}\right)\right], \tau \in\left(\tau_{n-2}, \tau_{n-1}\right)
$$

Theorem 8: The recursive loan-pricing equation is as follows:

$$
P(\tau)=\Gamma_{\tau}\left[\min \left\{C_{n-1}+\Gamma_{\tau_{n-1}^{+}}\left[\min \left[V\left(\tau_{n}\right), C\left(\tau_{n}\right)\right]\right], V\left(\tau_{n-1}\right)\right\}\right], \tau \in\left(\tau_{n-2}, \tau_{n-1}\right)
$$

At the moment $t=\tau_{n-2}$, the equation of the pledged loan-to-value ratio is as follows:

$$
\Gamma_{\tau}\left[\min \left\{C_{n-1}+\Gamma_{\tau_{n-1}^{+}}\left[\min \left[V\left(\tau_{n}\right), C\left(\tau_{n}\right)\right]\right], V\left(\tau_{n-1}\right)\right\}\right]=x V\left(\tau_{n-2}\right)
$$

Proof of theorem 8: Make simultaneous equations of equations (22) and (23). Then, according to the principle of fair pricing, we can get it.

Thus, through step-by-step derivation, we can get the value of the loan and the determining equation of the pledged loan-to-value ratio at any moment. Using a numerical algorithm, we can figure out the value of $x$ in equation (25).

The pledged loan-to-value ratio of a package of fixed-rate zero-coupon inventory pledge loans

This basic method can be extended to analyze many types of inventory pledge loans, for example, metal.

$$
\begin{aligned}
& \frac{d V_{1}}{V_{1}}=\mu_{1} d t+\sigma_{1} d z_{1} \\
& \frac{d V_{2}}{V_{2}}=\mu_{2} d t+\sigma_{2} d z_{2}
\end{aligned}
$$

The correlation coefficient of two Brownian motions is $\rho$. We are most concerned with the relationship between the quantity proportion of two types of metal $y, z$ and the pledged loan-to-value ratio.

Redefine the portfolio value as follows:

$$
V=y V_{1}+z V_{2}
$$

Replace $V$ in the second part we mentioned previously with $V$ in equation (28), and then use the same approach. Because the sum of geometric Brownian motions is not a geometric Brownian motion, to obtain the explicit solution, we need to determine an approximate option pricing formula. According to a study by Milevsky and Posner (1998), the approximate pricing formula of the option portfolio is as follows:

$$
\Phi_{\text {put-bas }}=e^{-r \tau} F N\left(\frac{\log \left(\frac{F}{K}\right)+\frac{\nu}{2}}{\sqrt{v}}\right)-V+K e^{-r \tau} N\left(\frac{\frac{v}{2}-\log \left(\frac{F}{K}\right)}{\sqrt{v}}\right)
$$

where

$$
\begin{aligned}
& F=y F_{1}+z F_{2}, \\
& F_{1}=V_{1}(0) e^{r \tau} \\
& F_{2}=V_{2}(0) e^{r \tau}
\end{aligned}
$$




$$
M_{2}=e^{v}=\frac{1}{F^{2}}\left[y^{2} F_{1}^{2} e^{\sigma_{1}^{2} \tau}+2 y z F_{1} F_{1} e^{\rho \sigma_{1} \sigma_{2} \tau}+z^{2} F_{2}^{2} e^{\sigma_{2}^{2} \tau}\right]
$$

The equation of the pledged loan-to-value ratio is as follows:

$$
e^{k \tau} N\left(-\frac{\log (x)+\frac{v}{2}+k \tau}{\sqrt{v}}\right)=1-\frac{1}{x} N\left(\frac{\log (x)-\frac{v}{2}-k \tau}{\sqrt{v}}\right) .
$$

The only difference with equation (13) is volatility $v$,which implies the quantity proportion of two types of metal and the correlation coefficient.

\section{A numerical example}

Due to space limitations, we only provide a numerical example for theorem 6 , equation (13). This visually displays how the pledged loan-to-value ratio changes with the term of the loan, the risk premium, the value volatility characteristics, etc. Equation (13) is an implicit function of $x$ with parameters $\sigma, \tau$ and $k$, thus we use the solve function in Matlab to achieve it. The result of the numerical example is consistent with our preceding theoretical analysis.

Given the risk premium $k=0.05$ and the value volatility of the pledged property $\sigma=0.25$, the relationship between the pledged loan-to-value ratio $x$ and the term of the loan $\tau$ is shown in Fig. 1. As we can see in the figure, with the loan terms extended from 1 year to six years, the pledged loan-to-value ratio gradually becomes smaller; i.e., for the same pledged property, the longer the loan term is, the smaller the loan amount will be. The pledged loan-to-value ratio $x$ is a convex decreasing function of the term of the loan $\tau$.

Given the risk premium $k=0.03$ and the term of the loan $\tau=6$, the relationship between the pledged loan-to-value ratio $x$ and the value volatility of the pledged property

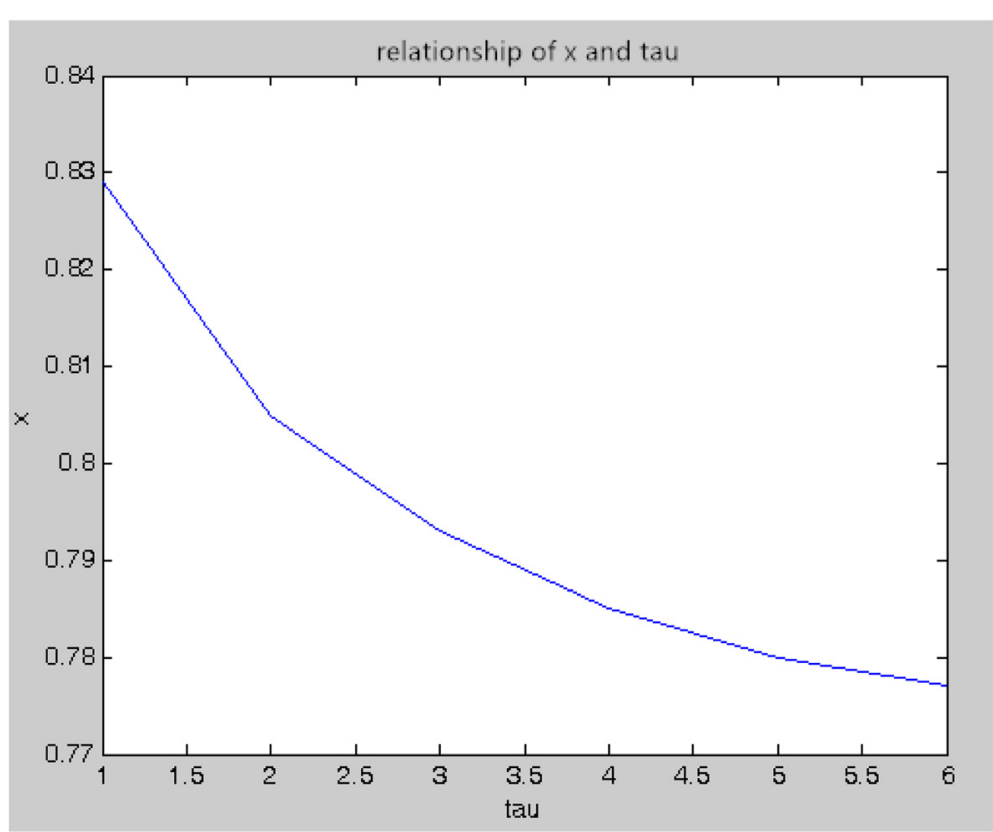

Fig. 1 The relationship between the pledged loan-to-value ratio and the term of the loan 
$\sigma$ is shown in Fig. 2. As in Fig. 2, the pledged loan-to-value ratio decreases with an increase in the value volatility of the pledged property. An increase in the value volatility of the pledged property increases the risk. Given the same loan term and risk premium, the funds that the bank is willing to lend will be reduced with an increase in the value volatility. The pledged loan-to-value ratio $x$ is a concave decreasing function of the value volatility of the pledged property $\sigma$.

Given the value volatility of the pledged property $\sigma=0.25$ and the term of the loan $\tau=6$, the relationship between the pledged loan-to-value ratio $x$ and the risk premium $k$ is shown in Fig. 3. As illustrated in the figure, the pledged loan-to-value ratio $x$ is a concave increasing function of the risk premium $k$. When the risk premium, which can be understood as the difference between the deposit interest rate and the loan interest rate, increases, the profitability of banks will increase and the capacity to bear risk will be enhanced. In this situation, for a pledged property with the same value volatility and loan term, the willingness of the bank to lend money will be stronger and the pledged loan-tovalue ratio will then increase.

\section{Conclusions}

To sum up, we investigated the pricing of an inventory pledge loan under an option pricing environment, analyzed the main factors that affected the pledged loan-to-value ratio, and provided a numerical example. The numerical simulation results show the term structure of the pledged loan-to-value ratio. The ratio varies with the term and is a convex decreasing function of the term. We can also conclude from the figure that the pledged loan-to-value ratio is a concave decreasing function of the value volatility of the pledge, and the larger the volatility is, the smaller the ratio will be. This can be used to analyze the manner in which the pledged loan-to-value ratio varies with pledges

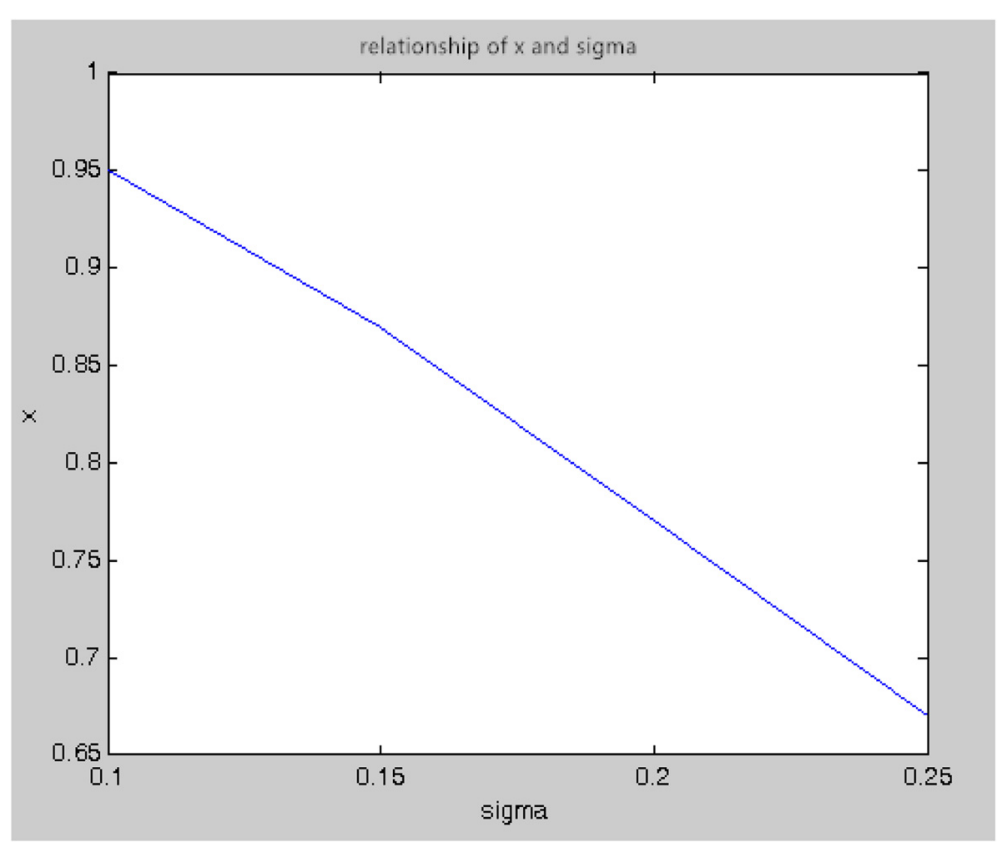

Fig. 2 The relationship between the pledged loan-to-value ratio and the value volatility of the pledged property 


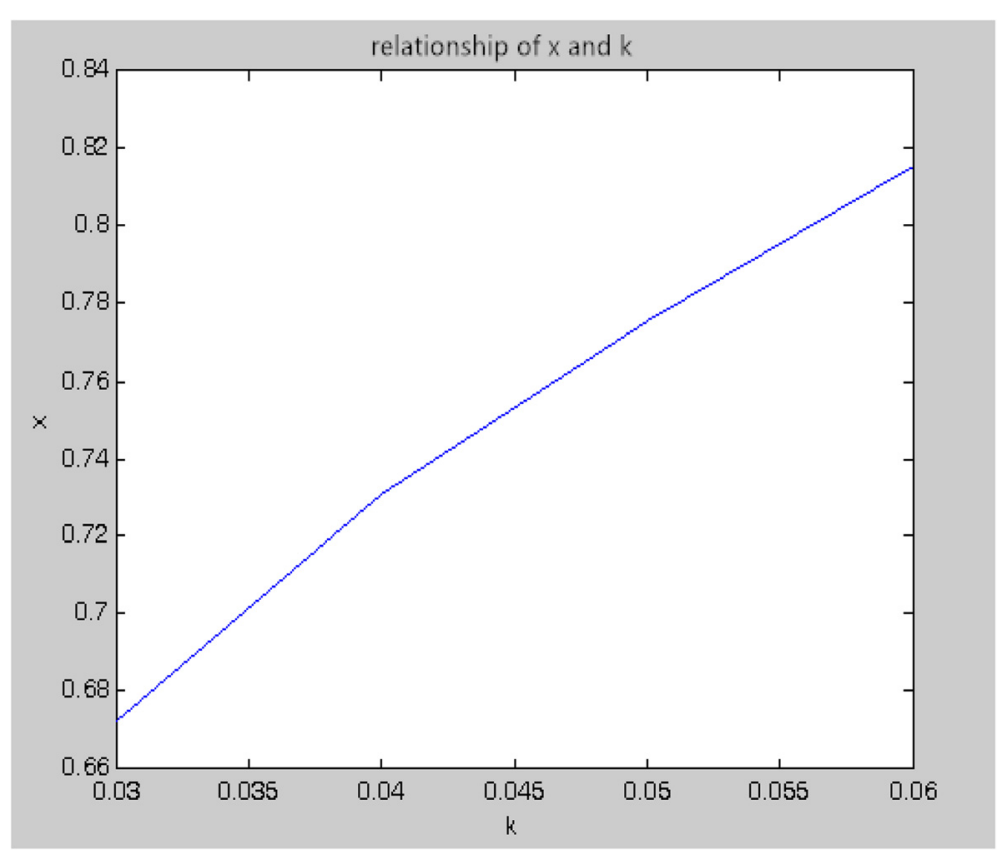

Fig. 3 The relationship between the pledged loan-to-value ratio and the risk premium

of different types of metal. In addition, the pledged loan-to-value ratio is a concave increasing function of the risk premium. When the risk premium increases, banks' capacity to bear risk will be enhanced and the ratio will increase. All these results are quite intuitive.

In practice, small banks lack methods and techniques to dynamically hedge such loans. Big investment banks could consider creating such derivatives and directly selling them to small financial institutions; this would provide new market space. In addition, the scientific measurement of the pledged loan-to-value ratio means that using simple rules of thumb or the VaR method may lead to mispricing, which could create the possibility of arbitrage. This provides a direction for trading derivative products of pledges. In this paper, the result is concluded in the situation of fixed interest rates. For floating interest rate circumstances, we should introduce a random interest rate process and specify the function form between the loan interest and the risk-free rate. The major limitation of this method is that the matter should be tradable. The option pricing method requires that sales of the underlying assets can be transacted dynamically with a low cost. If futures corresponding to the pledged properties exist, for example, metal futures, a dynamic hedge can be achieved through futures trading. For a pledged property with corresponding futures that are non-tradable or require expensive transactions, we should introduce risk appetite or use the traditional method to analyze. 


\section{Acknowledgements}

We appreciate the helpful comments of two reviewers. Ran thanks the financial support of National Science Fund of China (No. 71003005 and No. 71373002).

Received: 23 June 2015 Accepted: 12 November 2015

Published online: 03 December 2015

\section{References}

Alvarez-Ramirez J, Alvarez J, Rodriguez E (2008) Short-term predictability of crude oil markets: a detrended fluctuation analysis approach. Energy Econ 30(5):2645-2656

Arito O, Uchida H, Udell G, Uesugi I (2013). A close look at Loan-To-Value ratios: evidence from the Japanese Real Estate Market. Working Paper, Center for Interfirm Network, Institute of Economic Research, Hitotsubashi University, No. 19.

Black F, Scholes M (1973) The pricing of options and corporate liabilities. J Polit Econ 81(3):637-54

Buzacott JA, Zhang RQ (2004) Inventory management with asset-based financing. Manag Sci 24:1274-1292

Cossin D, Hricko T (2003) A structural analysis of credit risk with risky collateral: a methodology for haircut determination. Econ Notes 32(2):243-282

Cossin D, Huang Z, Aunon-Nerin D (2003) A framework for collateral risk control determination, vol 1, European central bank working paper series., pp 1-47

Duffie D, Singleton K (1999) Modeling term structure of defaultable bonds. Rev Financ Stud 12:687-720

Fan Y, Wei Y (2003) VaR based evaluation method for impawn rate of stock for combination. Syst Eng 4:86-89

Fernando A, Postali S, Picchetti P (2006) Geometric Brownian Motion and structural breaks in oil prices: a quantitative analysis. Energy Econ 28(4):506-522

He J, Jiang XL, Zhu DL, Wang J, Chen L (2012) VaR method for setting up the dynamic loan-to-value ratio of steel pledge loan in supply chain financing business. J Indust Eng Eng Manag 26(3):129-135

Huang Z, Liu Y, Zhu F (2009) Stock collaterals loan business and loan-to-value ratio analysis. Financ Theor Pract 9:92-95 Jarrow RA, Turnbull S (1995) Pricing derivatives on financial securities subject to credit risk. J Financ 50(1):53-85

Jarrow RA, Lando D, Turnbull S (1997) Markov model for the term structure of credit risk spreads. Rev Financ Stud 10(2): 481-523

Jokivuolle E, Peura S (2003) Incorporating collateral value uncertainty in loss given default estimates and loan-to-value ratios. Eur Financ Manag 9(3):299-314

Korteweg A, Sorensen M (2015) Estimating Loan-to-Value distributions. Real estate economics

Kuang HB, Zhang YF, Zhang LR (2013) A study on the pricing model of inventory pledge loan in low carbon port. Sci Res Manag 34(12):26-38

Li Y, Feng G, Xu Y (2007) Research on loan-to-value ratio of inventory financing under randomly-fluctuant price. Syst Eng Theor Pract 12:42-48

Merton RC (1973) Theory of rational option pricing. J Econ Manag Sci 4(1):141-183

Milevsky MA, Posner SE (1998) A closed-form approximation for valuing basket options. J Deriv 5(4):54-61

Qi E, Ma S, Han T (2008) Research on loan-to-value ratio of the combination of warehouse receipt. J Xidian Univ (Social Science Edition) 11:50-53

Stulz R, Johnson H (1985) An analysis of secured debt. J Financ Econ 14(4):501-521

Wang Z (2003) Determining loan-to-value ratio of stock collateral loans based on VaR method. J Financ Res 12:64-71

Wang CJ, Wei HG, Yang JL (2013) Optimal decision model of inventory loan-to-value ratio under the influence of price. Commercial Times 1:83-84

Zhang Q, Zhao Q (2010) Research on loan-to-value ratio of inventory pledge loan whose demand is stochastic. Chin J Manag Sci 5:21-27

\section{Submit your manuscript to a SpringerOpen ${ }^{\circ}$ journal and benefit from:}

- Convenient online submission

- Rigorous peer review

- Immediate publication on acceptance

- Open access: articles freely available online

- High visibility within the field

- Retaining the copyright to your article 